報文

(17)

\section{蒸気エセクタの特性と性能計算法についで}

植田辰洋灹

\section{1。緒言}

蒸気エビクタの作用は，ノズルからの蒸気噴流による 気体吸入の過程と、ディフューザに㧊ける圧縮過程から なっているが，その性能はかなり特異である。また幾つ かの異なった特性をとりらる。このため理論的に性能を 求めることは困難であるとされ，経験的な設計を行 ここ とが多かったように思和れる。しかし関保する因子が多 いため，この方法は必ずしも容易でない。そこで，本交 ではまず蒸気エゼクタの特性について考察し，吸入およ び圧縮過程に対して試みた些際的な計算方法, および性 能に関する二，三の問題について述べることにする。

\section{2. 蒸気エゼクタの特性について}

蒸気エゼクタ内の状態変化は外部条件によって幾つか の形式をとりこれに応じて特性も異なる***。 Fig. 1 は駆動蒸気の圧力, 吸入気体量を一定に保ち、ディフュ 一ザ出口外部俚力——背圧——だを变えて求めた実測 例である。ノズルからの高速蒸気流は吸入気体を加速し ながら、ディフューザの先細部，喉部，末広部を通る

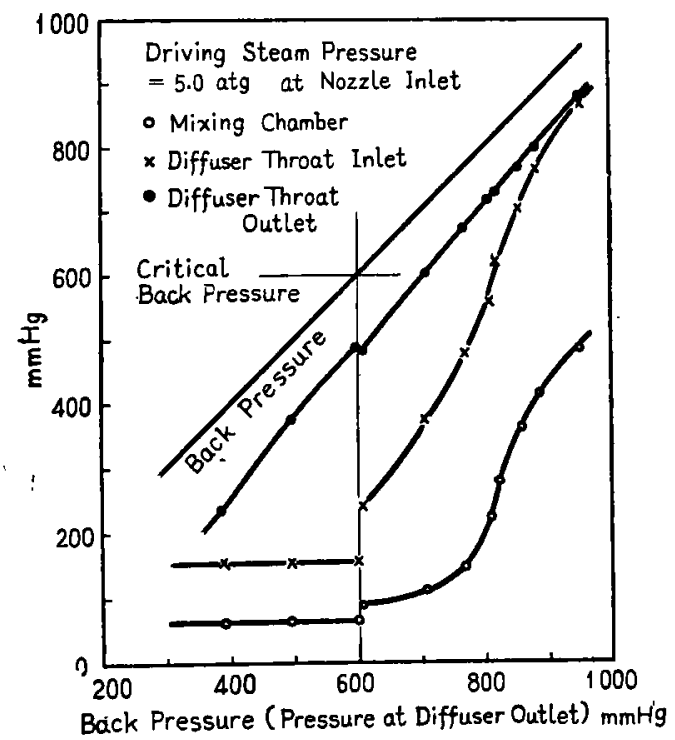

Fig. 1 An example of performance characteristics

* 昭和 34 年 12 月 23 日受理

** 東京大学工学部械工学教室

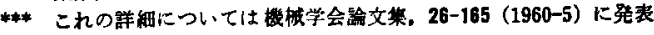
の余定
が，状態変化の形式は喉部に音速以上で達する場合と， 音速以下で達する場合とでは異なってくる。

喉部に音速以上の充满した流れとなって流入する場合 には，混合室㧍よび先細部の圧力は背圧には全く影響さ れないはずであって，Fig.1で背王が約 $600 \mathrm{mmHg}$ に 達するまでの状態はこれを示している。これを高真空特 性とよふことにする。喉部に音速以下の速度で流入する 場合，あるいは音速以上でも㔀離した流れとなって流入 する場合には，混合室圧力は背圧によって変動する。ま た音速以下のときの喉部内流れは，一般の管路と同様で あるから，圧力の変化は少ない。 Fig. 1 で背圧が 900 $\mathrm{mm} \mathrm{Hg}$ 以上Kなったときの状態はこの特性を示してい る。

真空度をできるだけ高くすること，おるいは高い压維 比を要求される一般の蒸気エゼクタに执いては，Fig. 1 から明らかなように高真空特性にあるべきであり，以下 述べる計算法もこの場合についてのものである。もちろ ん高真空特性の存在範囲は限られていて, 背圧がある限 界值に達すると一Fig. 1 では䄪 $600 \mathrm{~mm} \mathrm{Hg}$ 一流動 状態が急变し真空度が低下する。したがって蒸気エゼク 夕の性能を求めるには，混合室圧力と吸入量の関係すな わち吸入性能と, 高真空特性に批いて達し5る最高の背

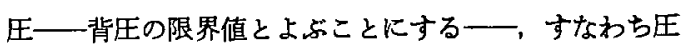
縮性能を求めればよいわけであって，背圧がこれより低 い場合の吸入性能は一定である。

\section{3. 吸入性能の計算法}

吸入気体は蒸気噴流に牽引されて混合室からディフュ 一ザに入り次第に加速される。ここで考劣る高真空特性 の状態に括いては，吸入気体はディフューザ先細部で音 速以上の速度に達する。このためエゼクタの吸入性能は ディフューザ先細部の比較的ノズルに近い部分まで，す なわちエぜタ前半の状態によって決定されることとな り，それ以後の状態には無関係である。したがって蒸気 エゼクタに扑ける気体吸入の原動力となるるのは蒸気の 率引力であり，その吸入量を規定するすのはエぜクタ前 半のディフューザの形状と蒸気噴流とによってきまる吸 入気体の流路状態であることが明らかとなる。

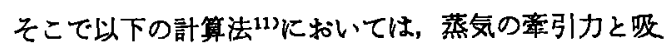
入気体の流路面積とから吸入量を考えることとした。 
Fig. 2 に拈いて,

$G:$ 流量 $\mathrm{kg} / \mathrm{s}, p$ : 圧力 $\mathrm{kg} / \mathrm{cm}^{2}, f$ : 面積 $\mathrm{cm}^{2}$, $\omega:$ 流速 $\mathrm{m} / \mathrm{s}, v=1 / r$ : 比容皘 $\mathrm{m}^{3} / \mathrm{kg}$, 添字 $s$ は蒸気, $a$ は吸入気体を 示し，また添字0は混合 室, 添字 1 は正常膨張に 淤けるノズ出口状熊を 表わす。 $f_{1}$ はノズル出 口断面積， $f_{a 0}$ はノズル 先端とディフューザ間の 最短距離における吸入気 体の通路面積 ( $w_{a 0}$ はこ れを通る気体の軸方向の 速度成分)，Lはノズル 出口からの距﨎 $m$ であ

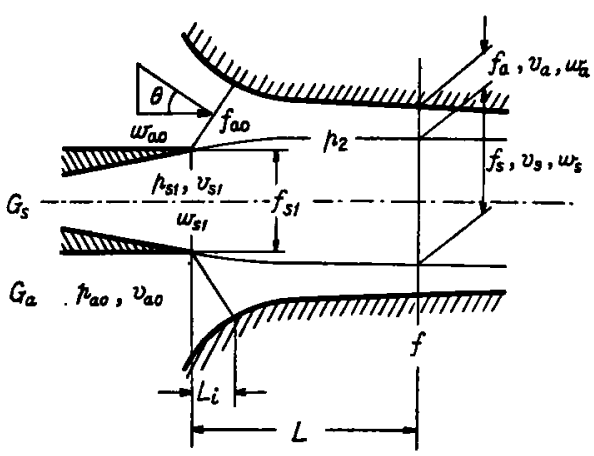

Fig. 2 Diffuser inlet

$f_{a 0}$ represents a passage area where the distance between nozzle tip and diffuser wall is shortest. The pressure of entrained fluid- $p_{a 0}$ in the mixing chamber-drops to $p_{2}$ at $f_{a 0}$. $w_{a 0}$ represents the axial component velocity of entrained fluid.

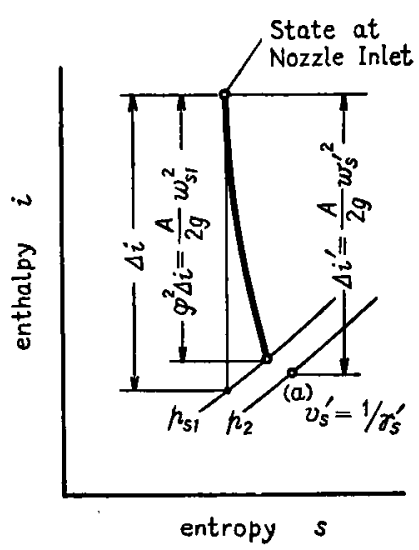

Fig. 3 i-s diagram for steam $\varphi$ stands for the velocity coefficient of nozzle. State $(a)$ is obtained from the following equation,

$$
\frac{G_{s}}{g} w_{s 1}+f_{s 1} p_{s 1}=\frac{G_{s}}{g} w_{e}^{\prime}+f_{s 1} p_{2}
$$
る。

3-a） まず基準として蒸気が等圧 $p_{2}$ の下で吸入気 体を加速するとした場合を考えてみる。この場合, 蒸気 の運動量に関しては位置 $L$ (この位置のディフューザ断 面棈はf）において次式が成立する。

$$
\frac{G_{s}}{g} w_{s 1}+f_{s 1} p_{s 1}=\frac{G_{s}}{g} w_{s}+f_{s 1} p_{2}+P
$$

これつ $P$ は蒸気噴流の率引力 $\mathrm{kg}$ であって,

$$
\begin{gathered}
P=\int_{0}^{L} x \frac{\gamma_{b}}{2 g}\left(w_{s}-w_{a}\right)^{2} d O \fallingdotseq \chi^{\prime} \frac{r_{s}^{\prime}}{2 g} w_{a}^{\prime 2} \times O \\
た た ゙ し, \quad O=\pi d_{a}^{\prime} L \times 10^{-2}
\end{gathered}
$$

上式において， $\chi$ は旁引係数， $O$ は蒸気噴流の表面積 $\mathrm{m}^{2}$, また $w_{\mathrm{a}}{ }^{\prime}, d_{\mathrm{s}}{ }^{\prime}, r_{\mathrm{s}}{ }^{\prime}$ は

$$
\begin{aligned}
& \frac{G_{s}}{g} w_{s 1}+f_{s 1} p_{s 1}=\frac{G_{a}}{g} w_{s}^{\prime}+f_{s 1} p_{2} \\
& \frac{\pi}{4} d_{s}{ }^{\prime 2}=f_{a}^{\prime}=\frac{G_{s}}{r_{s}^{\prime} w_{s}^{\prime}} \times 10^{4}
\end{aligned}
$$

から求められる值，また $\chi^{\prime}$ は実験的に決定すべき引 係数で, 従来のエゼクタの実験結果 2 ' 温の空気—からは

$$
\mathbf{x}^{\prime} \doteqdot 0.01
$$

と扰くのが適当である。ただしこの值は吸入気体の速 度分布などに関係し，エゼクタの大きさや吸入気体の性 質によって幾分变化するものと思われる。なおこのとき の吸入冣体の流路面積は

$$
f_{a}=f-f_{s}=f-\frac{G_{s} v_{s}}{w_{s}} \cdot \times 10^{4}
$$

吸入気体についてす位膡 $L$ において次式か成立する。 ただし吸入気体の圧力は $f_{a 0}$ において $p_{a 0}$ から $p_{2}$ に低 下し以後一定であり、ディフューザ壁の摩擦抗力は無視
するものとする。

$$
\begin{aligned}
& \frac{G_{a}}{g} w_{a 0}+P=\frac{G_{a}}{g} w_{a} \\
& w_{a 0}=\frac{G_{a} v_{a}}{f_{a 0}} \cos \theta \times 10^{4} \\
& f_{a}=-\frac{G_{a} v_{a}}{w_{a}} \times 10^{4}
\end{aligned}
$$

以上の式においてノズル前の蒸気状態が与えられれ ば, Fig. 3 のごとく蒸気の $i-s$ 線図上で $f_{A 1}$ に対して $p_{\mathrm{a} 1}, v_{\mathrm{s} 1}, w_{\mathrm{s} 1}$ が求められる。なお $\varphi^{2}=0.88 \sim 0.93$ であ る。また四の (a) 点によって（2）式の $\gamma_{s}{ }^{\prime}$ が決定され るが，これと位置 $L$ における $\gamma_{s}=1 / v_{s}$ との差は無視で きる程度である。すなわち

$$
v_{\mathrm{s}} \fallingdotseq v_{\mathrm{s}}{ }^{\prime}, \quad \gamma_{\mathrm{s}} \doteqdot \gamma_{\mathrm{a}}{ }^{\prime}
$$

さて以上のことから実際にはつぎよ5に計算を行 5。ます指定された $p_{2}$ において (1)，(2)，(3) 式から おのおのの位置 $L$ に対する $f_{a}$ を求める。つきに $G_{a} w_{a 0} / g=P_{0}$ とおいて，この值を仮定すると（4）式と (6) 式から，次式によって吸入量が決定される。

$$
G_{a}=\sqrt{f_{a} \frac{g}{v_{a}}\left(P_{0}+P\right)} \times 10^{-2}
$$

この $G_{a}$ は仮定した $P_{0}$ に対し，各位置において吸入 しうる量を示するのであって，一般に Fig. 4 の BDE のごとき傾向の曲線になり，ある位直 $L_{m}$ において極少 值をとる。したがって等扯という条件のるとで吸入しう る量はこの極少值である。そして，これはもちろん仮定 した流入による運動量 $P_{0}$ をす湍尼しなければならな い。そこで求まった極少值を $G_{a 0}$ として，これを(5) 式の $G_{a}$ に代入して $w_{a 0}$ を求め, この両者から求まる $G_{a 0} w_{a 0} / g=P_{0}^{\prime}$ が，仮定した $P_{0}$ と等しくなるまで， $P_{0}$ 


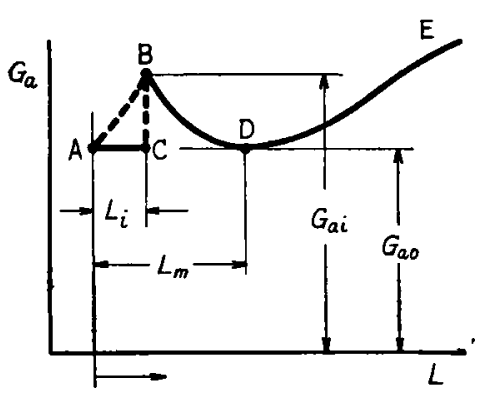

Fig. $4 G_{a}$ vs. $L$

$G_{a}$ represents the flow rate to be entrained in each section. AC and B correspond to $f_{a 0}$ and section $L_{i}$, respectively.

を仮定しなおして計算する。すなわち $f_{a 0}$ を通過する吸入気体量と $G_{a 0}$ とが 等しくなるようにする。かくして求ま った $G_{a 0}$ がこの圧力 $p_{2}$ Kおける吸入
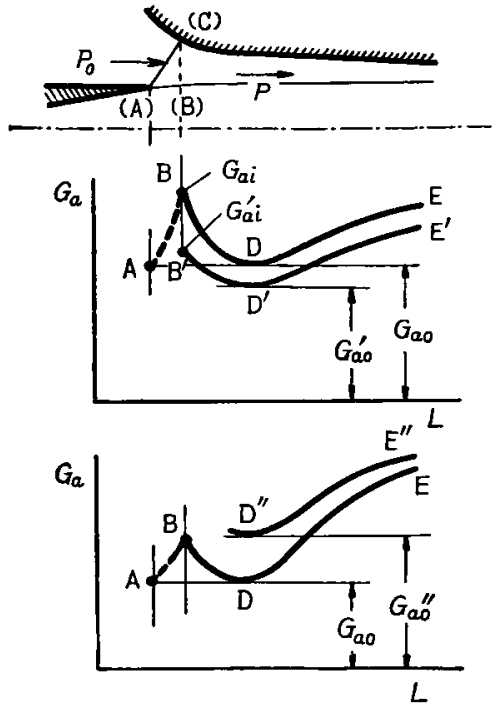

Fig. 5 Pressure variation
なる限界值をきめこれが I.35 以下である場合は等圧 とみなし， $G_{a i} / G_{a 0}>1.35$ の 場合は压力上年による修正を 行らこととした。この修正は つきのよろに行う。すなわら 压力上梨を生するる当然 $L=$ 0 $L_{i}$ の間で, つまり Fig. 5 の $\mathrm{AC}, \mathrm{BC}$ 間で $P_{0}, P$ と反 対方向の力を生ずるはずであ る。これを $P_{1}$ とし，

$$
P_{0}-P_{1}=P^{*}
$$

とおき， $P^{*}$ を(7) 式の $P_{0}$ に打が、幾つか仮定した $P^{*}$ の值に対して $P_{0}$ の場合 と同样に計算し，Fig. 5 の $\mathrm{B}^{\prime} \mathrm{D}^{\prime} \mathrm{E}^{\prime}$ なる $G_{\mathrm{a}}$ 曲楾を求め, $G_{a i}{ }^{\prime} / G_{a 0}{ }^{\prime}=1.35$ となったと 量である。したがって $p_{2}$ に対して $f_{a 0}$ を通過するとき の吸入気体の圧力降下一これはわずかの值であるが 一考睢すれば $p_{a 0}$ と $G_{a 0}$ との関係が求まるわけで あり、これが等圧のもとで蒸気が吸入気体を加速すると 考えた場合の吸入性能となる。

3-b） 以上は等圧という仮定に基ついた計算である がこの仮定が常に満足されるとは考えられない。これ に対しては以上によって求められた結果と, 従来行われ ている多くの実験結果 ${ }^{2,7,9)}$ とを比較することによって求 めた二つの経験的条件を設けて，以下述へるように考虑 することとした。

(b-1） Fig. 4 の $L_{i}$ における吸入量を $G_{a i}$ とする 々， $G_{a i}>G_{a 0}$ であるが，実際には吸入量は $L$ に無関係

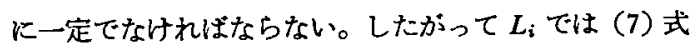
から明らかなとおり, 吸入気体の通路面積 $f_{a}$ か $G_{a 0}$ を 通過さすに必要な面積より大である。ここで吸入気体の 各断面に拊方速度を考えてみるに，その速度分布は $L$ が小なるほど不平等である。そして一般に同一流量が同 一運動量で流れる場合は，速度分布が不平等なるほど大 なる通路面積を要する。したがって上述のように吸入気 体流路に打ける速度分布が一様であるとして計算した場 合, Fig. 4 の $G_{a i}$ が $G_{a 0}$ よりある程度大であっても等 压という仮定は近似的成立すると考穴て差支えない。 しかし $G_{a i}$ が $G_{a 0}$ よりある程度以上大になれば，音速 以下に拈ける末広管と同様に Fig. 4 の AC, BC の間で 欧力上䄯が生ずるむのと考えなければならなくなる。

そこで第一の経娩的条件として

$$
G_{a i} / G_{a 0}=1.35
$$
きの極少值 $G_{a 0}{ }^{\prime}$ をってこの場合の吸入量とする。

（b-2）つきに $L_{m}$ 以後，すなわち DE について考

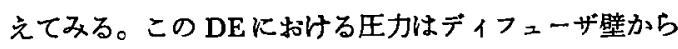
測定した結果らによると, 明らかて一度圧力降下を示し ている。そこでつきのことが考えられる。すなわち $G_{a}$ 曲線の DE に相当する部分では流れの圧力は降下する が, DE に括ける $G_{a}$ の增大 (したがって $f_{a}$ の增大) の 仕方が急激になれば DEに打ける圧力降下の影锌が前方 に及んで， $L_{m}$ よりノズル側でも幾分王力が下り，さら に吸入する傾向になってくるのではないであろうか。一 方, 上述の計算によって求めた吸入量と，実験における 吸入量とを比較してみるに，DEにおける $\left(G_{s}+G_{0}\right) /$ $\left(G_{a}+G_{a 0}\right)$ が一定值より大である場合は，例外なく計算 值より実験値の方が大であった。

そこで上の考えはほぼ正しいと思われるから，第二の 経験的条件として，L=L $L_{m}+\frac{d_{m}}{4}$ (ただし， $d_{m} は L_{m}$ の 断面におけるディフューザ直径) の位置において

$$
\left(G_{s}+G_{a}\right) /\left(G_{s}+G_{a 0}\right)=1.020
$$

なる限界をきめ,これが 1.020 以下である場合は等圧の ままで計算し，これが 1.020 以上であれば $L \leqq L_{m}$ にお ける等圧といら条件はもは中安定でなく，压力降下を生 じてこの値が 1.020 になるまで吸入量が增大すると考之 る。このときの吸入気体は $P_{0}, P$ のほかにさらに圧力降 下に上って力をらけるわけであり，これを $P_{2}$ と表わし， $P_{0}+P_{2}=P^{*}$ とし (b-1) の場合と同様に $P^{*}$ を(7) 式 の $P_{0}$ に代入し, 求をった $\mathrm{D}^{\prime \prime} \mathrm{E}^{\prime \prime}$ なる $G_{a}$ 曲線に执いて $\left(G_{s}+G_{a}\right) /\left(G_{s}+G_{a 0}\right)=1.020$ となったときの極少值 $G_{a 0}{ }^{\prime \prime}$ がこのときの吸入量となる。 
なお以上 (b-1)，(b-2) における括力 上界，王力降下は $p_{2}$ に比して無視し了 る程度である。したがってこの場合の吸 入性能す $p_{2}$ から吸入気体が $f_{a 0}$ を通過 するときの圧力降下を引くこととよって 求められる。

3-c） 以上のほかに $G_{a}$ 曲線に極少

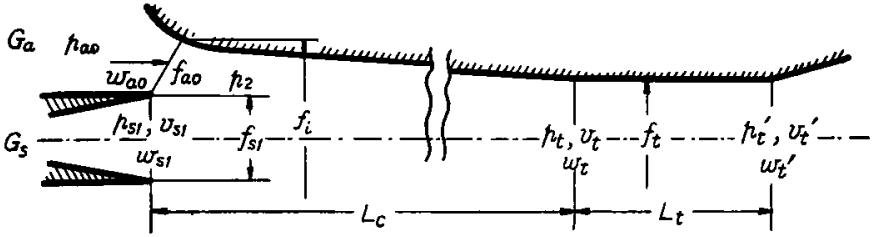

Fig. 6 Convergent part and throat of diffuser

值を生じないことがある。これには $G_{a}$

曲線が $L$ の增大ととむに単調に减少する場合と，增加 する場合とがある。

$G_{a}$ 曲線が単調に减少する場合は，この代力 $p_{2}$ におけ る吸入量は0であることを示す。

$G_{a}$ 曲線が単調に增加する場合は，デイフューザに吸 入された気体は直ちに㔀離する状態で，渦を生じ蒸気貲 流による牽引力は一部しか有効に作用せず，吸入性能が 著しく低下してくる。このような設計は好ましくない。

\section{4. 压樎性能の計算法}

蒸気エゼクタのディフューザ内の過程は，蒸気噴流に よる吸入気体の加速混合と, 速度エネルギの圧力への変 換の二つからなっている。しかし従来の計算法では，， ズルを出た蒸気は直ちに吸入気体と完全に混合するとし て，加速過程を無視してあるため，実際の設計にはあま り有効ではない。そこで本交では，加速過程をる考虙し た計算法を試みた。

\section{4-a）ティフューザ先細部}

Fig. 6 と打ける記号は Fig. 2 と同様である。ただし 添字 $t$ はディフューザ喉部入口， $t^{\prime}$ は喉部出口を表わす。 また $L_{c}$ はノズル出ロからディフューザ㬋部入口までの 距離 $\mathrm{m}, L_{t}$ は喉部長さ $\mathrm{m}$ である。な打吸入気体量の駆 動蒸気量に対する割合を

流量比 $\mu=G_{a} / G_{s}$

とする。

ディフューザ先細部に運動量の法則を適用するとつき のよ5になる。ディフューザ入口部においては

$$
\frac{G_{s}}{g} w_{s 1}+p_{s 1} f_{s 1}+\mu \frac{G_{s}}{g} w_{a 0}+p_{2}\left(f_{i}-f_{s 1}\right)
$$

つきにディフューザ喉部入口においては，蒸気と吸入気 体は混合して，この断面全体にわたって圧力と比容皘は 等しく，速度分布は Fig. 7 のよ5に，G，に相当する量 は面積 $f_{a t}$ を $w_{s t}$ の速度で， $G_{a}$ に相当する量は $f_{a t}$ を $w_{a t}$ の速度で通過すると仮定する。このようにするとデ イフェーザ搌部入口では

$$
\frac{G_{s}}{g} w_{s t}+\mu \frac{G_{s}}{g} w_{a t}+p_{t} f_{t}
$$

ゆえに運動量の関係は上式に先細部壁面の力を考虑する

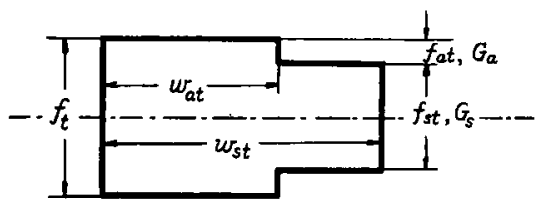

Fig. 7 Assumed velocity distribution

ことによって示される。

$$
\begin{aligned}
& \frac{G_{s}}{g} w_{a 1}+p_{s 1} f_{s 1}+\mu \frac{G_{b}}{g} w_{a 0}+p_{2}\left(f_{i}-f_{n 1}\right) \\
& =\frac{G_{s}}{g} w_{s t}+\mu \frac{G_{s}}{g} w_{a t}+p_{t} f_{t}+\zeta \frac{p_{2}+p_{t}}{2}\left(f_{i}-f_{t}\right)
\end{aligned}
$$

この最終項は先細部壁面の軸方向の力であり，係数 $\boldsymbol{\zeta}$ は先細部内の圧力変化の状態によってきまるもので, 計 算に扎いてはつき值をとるのが適当と思われる10)。

$$
\zeta \fallingdotseq 1.00 \sim 1.05
$$

ここで侯部入口における運動量および流量に関する平 均流速を考えることとし，これを $w_{M !}, w_{G t} \mathrm{~m} / \mathrm{s}$ とする と

$$
\begin{gathered}
w_{M t}=\frac{G_{s} w_{s t}+G_{a} w_{a t}}{G_{s}+G_{a}} \\
w_{M t} / w_{G t}=1+\Delta_{l}
\end{gathered}
$$

と括くと（11）式は

$$
\begin{aligned}
& \frac{G_{s}}{g} w_{s 1}+p_{b 1} f_{i 1}+\mu \frac{G_{t}}{g} w_{a 0}+p_{2}\left(f_{i}-f_{t 1}\right) \\
& =(1+\mu)\left(1+\Delta_{1}\right) \frac{G_{s}}{g} w_{G t}+p_{t} f_{t}+\zeta \frac{p_{2}+p_{t}}{2}\left(f_{i}-f_{t}\right)
\end{aligned}
$$

これに打いて，左辺は吸入性能から明らかになっている 值であり，また $\left(1+\Delta_{1}\right)$ の值は Fig. 8 から $K L_{0}$ に対 して求められる。

なお Fig. 8 は駆動蒸気と吸入気体にそれぞれ運動量 の法則を適用し，等圧のもとで加速するとして次式を解 いて求めたるのである(0)。

$$
\left\{\begin{array}{l}
\frac{G_{s}}{g} d w_{s}+d P=0 \\
\frac{G_{a}}{g} d w_{a}-d P+d W^{\prime}=0
\end{array}\right.
$$




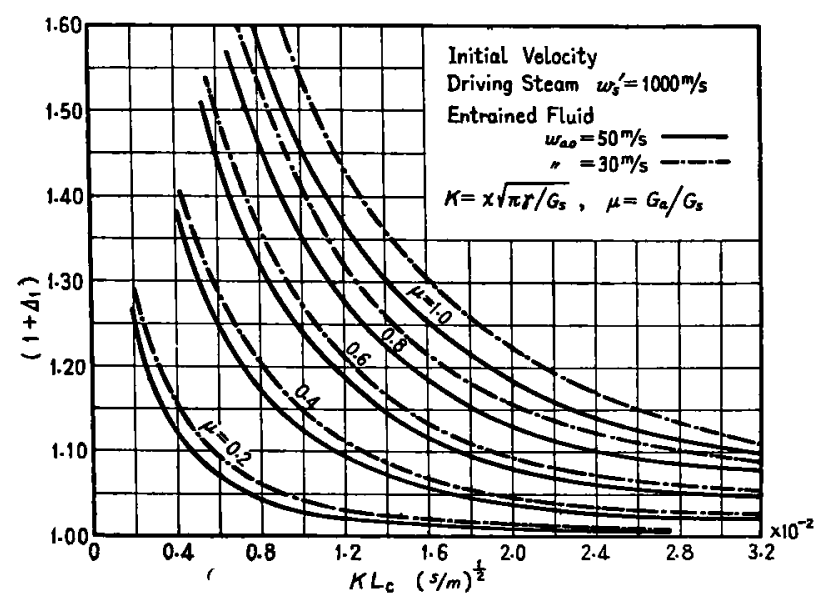

Fig. $8\left(1+\Delta_{1}\right)$ vs. $K L_{c}$

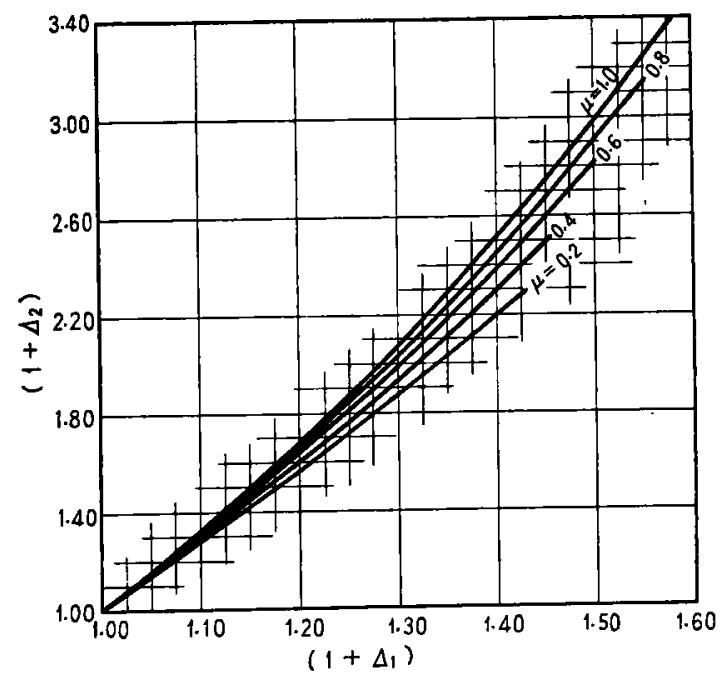

Fig. $9\left(1+\Delta_{2}\right)$ vs. $\left(1+\Delta_{1}\right)$

ただし

$$
\begin{aligned}
& d P=x \frac{r}{2 g}\left(w_{s}-w_{a}\right)^{2} \cdot 2 \sqrt{\pi f_{s}} \cdot d L \\
& d W=\lambda \frac{\gamma}{2 g} w_{a}^{2} \cdot 2 \sqrt{\pi f} \cdot d L
\end{aligned}
$$

これにおいて， $x$ は両流体間作用する率引保数、入 は吸入気体とディフューザ間の摩拯係数である。图にお いて, $K=\chi \sqrt{\pi \gamma / G_{0}}$, 計算に際しては $x \fallingdotseq 0.03, \gamma=$ $2 /\left(\frac{v_{a}^{\prime}+\mu v_{a}}{1+\mu}+v_{t}\right)$ とおくのが適当である。

したがって潪部入口の状態はつきのようにして求めら

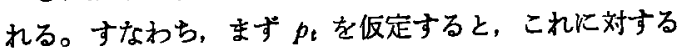
watが (13) 式から求められる。そこでこの $w_{G !}$

$$
F=(1+\mu)-\frac{G_{B}}{w_{G t}} \cdot v_{t} \times 10^{4}
$$

に代入すると，仮定した $p_{t}$ における所要通路面皘が求

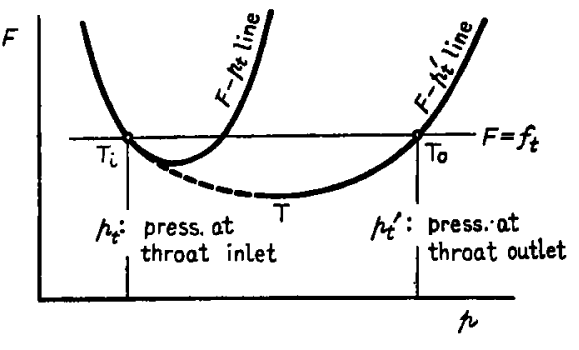

Fig. $10 F$ vs. $p_{t}$ and $p_{t}^{\prime}$

まるわけであるが、これは $f_{t}$ に等しくなら なければならない。すなわら種くの $p_{t}$ 汶対 して $F$ を求め， $F=f_{t}$ となったときの $p_{t}$ が 喉部入口压力になるわけである。

そころで (14) 式の $v_{t}$ の値は以上のこと からはかからない值であり、エネルギの関係 から求めなければならない。いま喉部入口に括ける 速度エネルギに関する平均流速を $w_{E t} \mathrm{~m} / \mathrm{s}$ とする と,

$$
w_{E t}{ }^{2}=\frac{G_{b} w_{s t}{ }^{2}+G_{a} w_{a t}{ }^{2}}{G_{b}+G_{a}}
$$

これと流量関する平均流速 $w_{G !}$ との比を

$$
w_{E t}{ }^{2} / w_{G}{ }^{2}=1+\Delta_{2}
$$

と表わすと，この值は $\left(1+\Delta_{1}\right)$ と $\mu$ だかから決定 され，Fig. 9 によって求められる ${ }^{103}$ 。ゆ元に喉部 入口の速度エネルギ $\Delta i_{\mathrm{t}}$ は, 上の $w_{G t}$ から

$$
\Delta i_{t}=-\frac{A}{2 g} w_{E t}{ }^{2}=\left(1+\Delta_{2}\right) \frac{A}{2 g} w_{G t^{2}}
$$

いま $i_{\mathrm{a} 0}$ をノズル前蒸気のエンタルピ $\mathrm{kcal} / \mathrm{kg}$ ， $i_{a 0}$ を混合室に和ける吸入気体のエンタルピ kcal/ $\mathrm{kg}$ とすると, ディフューザ内の流動は断熱体系と 考えられるから

$$
i_{t}=\frac{i_{s 0}+\mu i_{a 0}}{1+\mu}-\Delta i_{t}
$$

Фえに仮定した $p_{t}$ とこの $i$ とから，混合気体の $i-s$ 線 因上に括いて状熊が決定され， $v_{\boldsymbol{t}}$ が求められる。

この計算は種々の仮定した $p_{\imath}$ に対して行5必要があ るが， $p_{t}$ と $F$ の関係は Fig. 10 のよろになり、 $\mathrm{T}_{\mathbf{i}}$ 点 の王力が堠部入口王力である。

なおこれに批ける $f_{t}$ 線と $F-p_{t}$ 線とが交らないことす ある。これは高真空特性状態では流れは喉部を通過しえ ないすなわち高真空特性の存在しないことを示するの で，低い真空度しか得られないため好ましくない。

\section{4-b）ディフューザ喉部}

喉部に流入した駆動蒸気と吸入気体の混合物は，语撃 による急激な王力上年を生じて音速以下の流れに変る。 唯部長さを適当にとってあれば，喉部出口では蒸気と吸 
入気体とは完全混合していると考文て差支えない。し たがって啹部は運動量の法則から次式で計算できる。

$$
\begin{aligned}
& \left(1+\Delta_{1}\right)(1+\mu) \frac{G_{t}}{g} w_{G t}+p_{t} f_{t} \\
& =(1+\mu) \frac{G_{b}}{g} w_{t}+p_{t}^{\prime} f_{t}^{\prime}+W
\end{aligned}
$$

ただし，W は煀部の摩擦抗力 $\mathrm{kg}$ で，比較的小さい值で あるが。

$$
\begin{aligned}
W & =\int_{0}^{L t} \lambda \frac{r}{2 g} w^{2} \cdot 2 \sqrt{\pi f_{t}} \cdot d L \times 10^{-2} \\
& \fallingdotseq \lambda \frac{\sqrt{\gamma_{t} \cdot \gamma_{t}^{\prime}}}{2 g} w_{t} \cdot w_{t}^{\prime} \cdot 2 \sqrt{\pi f_{t}} \cdot L_{t} \times 10^{-2}
\end{aligned}
$$

これに拉いて，スは摩擦保数で 0.005 程度の值をとり， $r_{t}=1 / v_{\imath}, \gamma_{t}^{\prime}=1 / v_{t}^{\prime}$ である。な扰 (16)，(14）式に相 当する啹部出口に猢る関係は

$$
\begin{aligned}
& \Delta i_{t}{ }^{\prime}=\frac{A}{2} g w_{t}{ }^{2} \\
& F=(1+\mu) \frac{G_{s}}{w_{t}}, v_{t}{ }^{\prime} \times 10^{4}
\end{aligned}
$$

したがって喉部出口の状態は喉部入口の場合と同梯に 一ただし $\left(1+\Delta_{1}\right),\left(1+\Delta_{2}\right)$ はとるに1 とみなせる 一 $p_{i}{ }^{\prime}$ を仮定し，(18) 式と（20）式から $w_{\mathrm{i}}^{\prime}$ と $v_{\mathrm{i}}^{\prime}$ を 求め， $F$ を出すことができる。

この計算を種々の $p_{t}^{\prime}$ について行うわけであるが，

Fig. 10 の $F-p_{t}{ }^{\prime}$ 線のように, このうち $F=f_{t}$ となった とき,すなわち $\mathrm{T}_{0}$ 点の $p_{t}^{\prime}$ の值が喉部出口区カ代でる。

\section{4-c）ディフューザ末広部}

これはディフューザ末広部の効率を推定することによ って, 容易に蒸気と吸入気体の混合物儿対する $i-s$ 線团 上から求められる。すなわち，Fig. 11 のようにディフ ニーザ隐部出口の状態を $\mathrm{T}_{0}$ とし，末広部効率をわとす ると、 $\mathrm{T}_{0}$ から等エントロピに引いた線の $\left(i_{\mathrm{A} 0}+\mu i_{a 0}\right) /$ $(1+\mu)$ との交点 $\mathrm{D}_{0}$ を求め, $\mathrm{T}_{0} \mathrm{H} / \mathrm{T}_{0} \mathrm{D}_{0}=\eta$ なる点 $\mathrm{H}$ を求めると, この点 $\mathrm{H}$ の匠力 $p_{c}$ がディフューザで王

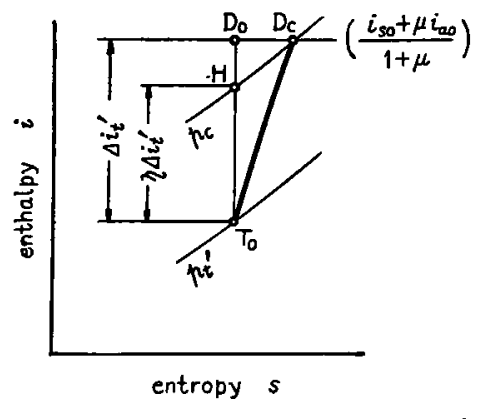

Fig. 11 i-s diagram for mixture $n$ is the efficiency of divergent part of diffuser. $T_{0}$ and $D_{c}$ represent the state of diffuser throat outlet and diffuser outlet, and $p_{c}$ is the critical back pressure obtainable.
縮しうる最高压力、すなわち背殴の限界值であり,ディ フューザ出口状態は $D_{0}$ で示される。ディフューザ出口 の速度エネルギは一般には無視できる程度である。

な招以上の上5にして背压の限界値が求められるが， 実際の使用に際しては背圧を限界值より幾分低く保つべ きである。このときには，流れは喉部の衝撃による压力 上年が完了しない状態—Fig. 10 の $\mathrm{T}_{i} \mathrm{TT}_{0}$ 線の途中の 状態一でっティフューザ末広部に入る状態变化をとる。

\section{5. 吸入爻体の性能に及ぼす影箒について}

駆動蒸気の圧力と混合室圧力 $p_{a 0}$ を一定に保っても， 吸入気体の種類や温度が巽なる場合には吸入量が変化す る。前述の吸入性能に対寸る計算法か5，吸入量は（7) 式から求をる $G_{a}-L$ 曲線の最少值 $G_{a 0}$ として求められ，

$$
G_{a 0}=\sqrt{f_{a} \frac{g}{v_{a}}\left(P_{0}+P\right)} \times 10^{-2}
$$

これにおける $P_{0}$ とPは（5）式および（2）式から

$$
\begin{aligned}
& P_{0}=\underset{g}{G_{a 0}} w_{a 0}=\frac{G_{a 0}{ }^{2}}{g} \cdot \frac{v_{a}}{f_{a 0}} \cos \theta \times 10^{4} \\
& P \fallingdotseq x^{\prime} \frac{r_{s}^{\prime}}{2 g} w_{s}^{\prime 2} \cdot \pi d_{s}^{\prime} L_{m} \times 10^{-2}
\end{aligned}
$$

一般に最少值 $G_{a 0}$ の現われる位置は，デイフューザ先 細部に批りるッバ状の入口部から直湶の先細部に移る 位置に一致し，吸入量に上ってほとんど変化しない。し たがって $L_{m}$ の值は土ゼクタが与えられると定まる值と 考齐てよい。また，この位㯰に拁ける圧力 $p_{2}$ は，吸入 気体が通路面䅡 $f_{a 0}$ を通るときのわすかの圧力降下に拉 ける気体の性質による相異を無視すると， $p_{a 0}=$ const. であるから $p_{2} \fallingdotseq$ const. とおくことができる。したがっ て上式を整理すると

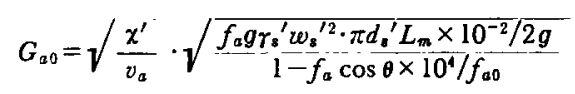

これから，駆動蒸気圧力と混合室圧力を一定にした場 合，与えられたエゼクタの高真空特性におけるる四入量は $\sqrt{x^{\prime} / v_{a}}$ に比例することになる。

吸入気体を完全がスと近似すると

$$
p v=R T=R T / M
$$

たたしし， $R$ はガス定数 $\mathrm{kg} \cdot \mathrm{m} /{ }^{\circ} \mathrm{K} \cdot \mathrm{kg} ， \boldsymbol{R}$ は一般ガス定 数 $=848 \mathrm{~kg} \cdot \mathrm{m} /{ }^{\circ} \mathrm{K} \cdot \mathrm{kmol}, M$ は分子量 $\mathrm{kg} / \mathrm{kmol}, T$ は 絶対温度 ${ }^{\circ} \mathrm{K}$ である。ゆ兄に，いむ基準にとる吸入気体 に対して*印を付し，その吸入量を $G_{a}{ }^{*}$ とすると，気体 の種類および温度の異なる場合の吸入量 $G_{a}$ との比は次 式で表わされる。

$$
\begin{aligned}
& \text { 吸入比 } \xi={ }_{G_{a}^{*}}^{G_{a}}=\sqrt{\chi^{\prime}} \cdot \sqrt{\chi_{v_{a}^{\prime}}^{v^{*}}} \\
& =\sqrt{\frac{x^{\prime}}{\chi^{\prime *}}} \cdot \sqrt{\frac{M}{M^{*}}} \cdot \sqrt{\frac{T^{*}}{T}}
\end{aligned}
$$




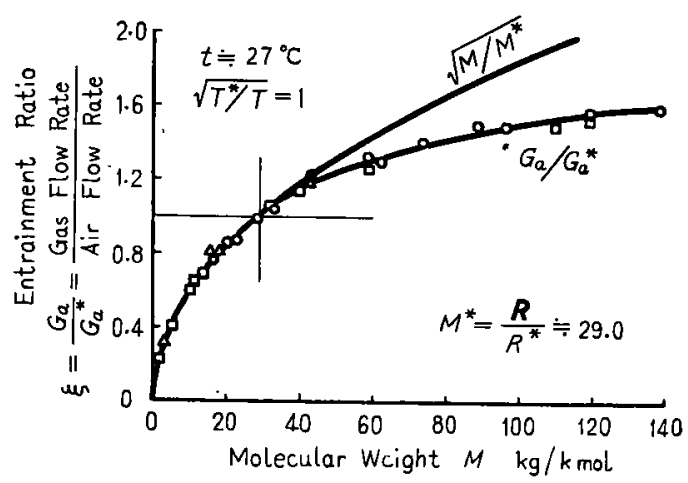

Fig. 12 Entrainment ratio vs. molecular weight and $\sqrt{M} / M^{*}$

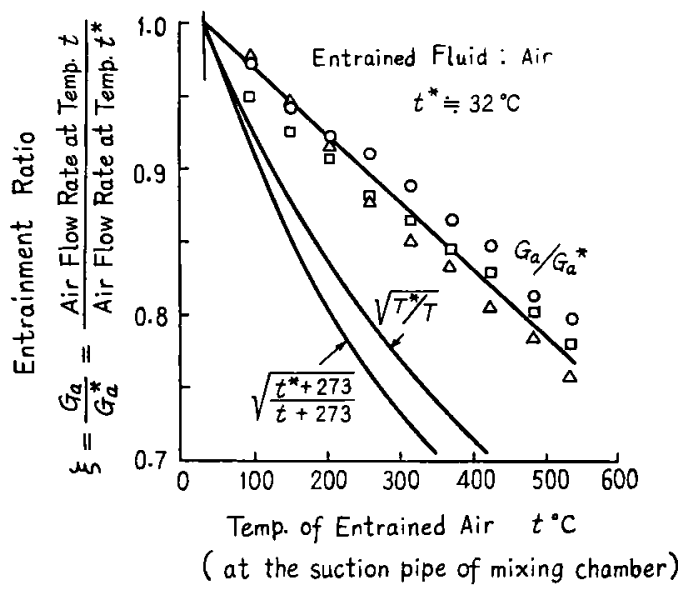

Fig. 13 Entrainment ratio vs. temp. and $\sqrt{T^{*} / T}$ $T^{*}$ and $T$ represent the temp. of entrained fluid at the convergent part of diffuser on the assumption that $T^{*}=t^{*}+273, T=t+273-0.2\left(t-t^{*}\right)$ where the temp. drop is taken into consideration. $t^{*}$ is the temp. of entrained fluid at a base state.

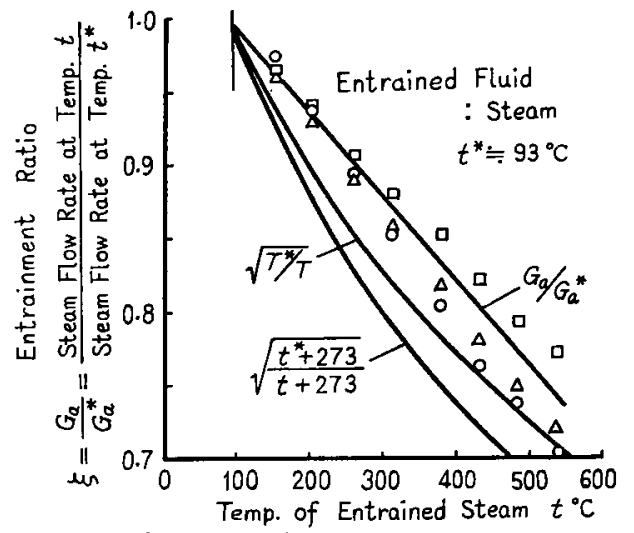

(at the suction pipe of mixing chamber)

Fig. 14 Entrainment ratio vs. temp. and $\sqrt{T^{*} / T}$ $T^{*}$ and $T$ are obtained in the same way as in Fig. 13.

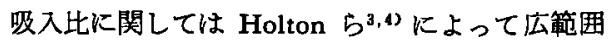
の実験が行われており，また考察のも行われている。 したがって Holton らの実験結果と（24）式を比較 することによって，㐮引係数 $\boldsymbol{x}^{\prime}$ の傾向を知ること ができる。なお，Holton らの実験は 3 4 種のエぜ クタについて,それぞれ外部条件一一駆動蒸気圧力, 混合室圧力および背圧一一を一定にして行われたも ので，背圧は常に大気圧である。

Fig. 12 は空気を基準四入気体とし，常温の種々 の気体を吸入したときの吸入比を求めた実験結果 ${ }^{3)}$ と， $\sqrt{M} / \bar{M}^{*}$ とを比較したものである。この場合 には $\sqrt{T^{*} / T}=1$ ，また $M^{*}=29.0$ である。この実 験状態では，分子量が大きくなり吸入量が增すと， 背圧の限界值は常に低下する傾向になる。したがっ て分子量が大であると，この限界値が大気圧以下と なるため高真空特性でなくなる。この場合には混合 室圧力は增大するが，それを所定の值に保つために は，当然吸入量を减じなければならない。したがっ て実駼值と（24）式の比較は，分子量が小さい範囲 において意味があるわけであるが，両方の曲線は $M<40$ の範囲では非常によく一致している。

Fig. 13, Fig. 14 は空気和よび水蒸気を吸入気体 とし、それぞれの温度を変劣た場合の吸入比の実験 結果 ${ }^{4)}$ と， $\sqrt{T^{*} / T}$ の比較である。な技実験結果は 吸入気体の流量測定部に批る温度 $t$ 飞対して示 されているが，(24）式の $T$ はディフューザ先細部 内の吸入気体温度である。したがって吸入気体が管 路, 混合室, 低温のノズルおよび蒸気噴流に接して 生ずる温度降下を考虑する必要がある。しかし，こ の温度降下は原論文からは推定できないので，図に は $\sqrt{\left(t^{*}+273\right) /(t+273)}$ と, $T^{*}=t^{*}+273, T=t+$ $273-0.2\left(t-t^{*}\right)$ とし，基準温度との羑の $20 \%$ 温 度降下を生ずると仮定して求めた $\sqrt{T^{*} / T}$ を示し た。たたし， $t^{*}$ は基準にとった温度で，空気の場 合は $32^{\circ} \mathrm{C}$, 水蒸気の場合は $93^{\circ} \mathrm{C}$ である。

以上のことから，率引係数 $x^{\prime}$ は吸入気体の種類 によってはあまり変化しないが，温度の上年ととも に增加する傾向にあるるのと考学られる。

\section{6. エゼクタの相似法則について}

幾何学的に相似なエぜクタを考党, その寸法比を l：nとしよう。寸法が $n$ 倍であるエゼクタの駆動 蒸気流量は, ノズル堠面䖽に比例するから $n^{2} G_{\text {。 }}$ : と なり、ノズル効率が一定ならばノズル出口の状態は 変化しない。また (22) 式の右辺において, $f_{a}, f_{a 0} \rightarrow$ $n^{2} f_{a}, n^{2} f_{a 0}$, また $d_{a}^{\prime}, L_{m} \rightarrow n d_{a}^{\prime}, n L_{m}$ となるから， 
牽引係数 メ' が变化しなければ，吸入量も $n^{2} G_{a}$ となる。 すなわち流量比 $\mu$ は変化しない。医縮性能む前述の計 算法から明らかなと括り，率引係数 $邓$ の活かに摩擦係

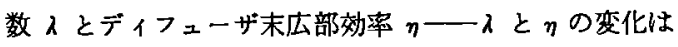
少ないと考えられるが一が同一ならば，同一の背圧の 限界値をらる。

エゼクタでは相似法則として知られている関係1 幾何学的に相似のエゼクタに沶いては，吸入量は寸法の 2 乗に比例する一がある。これは寸法比の小さい範用 で実験的に求められたるのであるが，上述の計算法から あ近似的にこの関係の成立することがわかる。な技法 比の大きいときには，特に率引係数 $x^{\prime}, x$ の变化のため に, この関㐿からずれることる考えられる。

\section{7. 蒸気一吸入気体混合物の $i-8$ 線図について}

正縮性能の計算に際しては, 駆動蒸気一吸入気体混合 物の $i-s$ 線四が必要である。つきに吸入気体が空気であ る場合を例にとり, その求め方を述べよう。蒸気が能和 状態である場合については，すでに谷下豆) の論文中に述 ベられているがここでは本交中の式に適用できる形で， 過熱状態である場合も含めて記すことにする。

いま, $R_{\mathrm{s}}$ : 蒸気の気体定数 $=47.06 \mathrm{~kg} \cdot \mathrm{m} / \mathrm{kg} \cdot{ }^{\circ} \mathrm{K}$, $R_{a}=$ 空気の気体定数 $=29.27 \mathrm{~kg} \cdot \mathrm{m} / \mathrm{kg} \cdot{ }^{\circ} \mathrm{K}, x$ : 蒸気の 乾き度 (過熱蒸気では1), $\mu=G_{a} / G_{s}$ : 流量比, $p_{8}$ : 蒸 気分圧 $\mathrm{kg} / \mathrm{cm}^{2}, p_{a}$ : 空気分圧 $\mathrm{kg} / \mathrm{cm}^{2}, p=p_{\mathrm{s}}+p_{a}$ : 全压 $\mathrm{kg} / \mathrm{cm}^{2}$ とし, 混合気体の比容積, 温度を $v \mathrm{~m}^{3} / \mathrm{kg}$, $T^{\circ} \mathrm{K}$ とすると

$$
\begin{gathered}
p_{\mathrm{a}} \times 10^{4} \doteqdot \frac{x}{1+\mu} R_{\mathrm{a}} \frac{T}{v}, \quad p_{\mathrm{a}} \times 10^{4}=\frac{\mu}{1+\mu} R_{a}-\frac{T}{v} \\
\therefore p_{\mathrm{s}}=\frac{x R_{\mathrm{a}}}{x R_{\mathrm{s}}+\mu R_{a}} \cdot p
\end{gathered}
$$

a) 和蒸気の場合 $\mu, p, x$ をぬる から ps が求められる。この $p_{s}$ に対する飽和温度を $T$. とすると，この場合は $T=T$ 。である。混合気体のエン タルピを $i \mathrm{kcal} / \mathrm{kg}$, エントロピを $s \mathrm{kcal} / \mathrm{kg} \cdot{ }^{\circ} \mathrm{K}$ とす ると

$$
\begin{aligned}
& i=\left[i_{s}+\mu c_{p a}\left(T-T_{0}\right)\right] /(1+\mu) \\
& s=\left[s_{s}+\mu\left(c_{p a} \ln \frac{T}{T_{0}}+A R_{a} \ln \frac{p_{0}}{p_{a}}\right)\right] /(1+\mu)
\end{aligned}
$$

ただし， $i_{s}, s_{s}$ は $p_{s}, x$ なる状態の蒸気 $1 \mathrm{~kg}$ のエンタル ピおよびエントロピ, $i_{p a}$ は空気の定圧比熱 $=0.242$ $\mathrm{kcal} / \mathrm{kg} \cdot{ }^{\circ} \mathrm{K}$ ，な技 $T_{0} ， p_{0}$ は任意の基準状態で， $T_{0}=$ $273.2, p_{0}=1 \times 10^{4}$ と扰ける。

b）過熱蒸気の場合 この場合 $\mu, p$ をあると $p_{s}$ が求まる。これに $T\left(>T_{\mathrm{s}}\right)$ を与えると，その状態の $i, s$ はやはり前式から計算される。ただし，この場合の

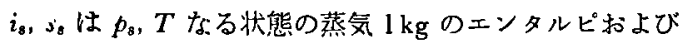
エントロピである。

な打此容積は次式で求められる。

$$
v=\frac{\mu}{1+\mu}-R_{a} \frac{T}{p_{a} \times 10^{4}}
$$

\section{8. 結 語}

一般の場合のように，高い吸入真空度あるいは高い仕 縮比を要求される蒸気エゼクタは, 高真空特性すなわら 駆動蒸気と吸入気体の混合物が、ディフューザ㗹部に音 速以上の充満した流れとなって流入する状態でなければ ならない。

この場合の吸入性能一吸入量と混合室厌力との関係 一は，ェゼクタの背压には無関係で，ディフューザ先 䋥部のノズルに比較的近い部分までの状態できる。 このことから，ノズルからの駆動蒸気の率引作用とディ フェーザ先細部の吸入気体流路とから吸入量を求める計 算法を試みた。ディフューザ内の王縮過程に对しては， 流量, 運動量怙よびェネルギに対するそれぞれの平均流 速を用いることによって，駆動蒸気と吸入気体の混合過 程をも考虑した計算法を述へ，高真空特性において達し 万る最高の背压すなわち限界値の求め方を示した。二ゼ クタの背壬が上升し背压の限界值を越すと，高真空特性 が存在しなくなって，混合室の真空度が急に低下する。

つきに以上の計算法から，吸入気体の影響を験べ，吸 入比一一種類，温度の異なる父体を吸入したときの吸入 量比一に対して (24) 式を導き, Holton らの実踰結 果と比較し，ノズルからの駆動蒸気の率引係数 $\boldsymbol{x}^{\prime}$ は分 子量によっては変化しないが，吸入気体の温度上年とと むに增加する傾向にあることを示した。また，エゼクタ の大きさによって牽引係数 $x^{\prime} ， x$ も幾分变化するものと 思われるが，その変化が小さい範囲では，近似的に土ぜ クタの相似法則の成立することを導いた。

な打本文のミ3，§4は筆者がすで発表した報告*か ら, 性能の計算に関倸ある事項を取出し，その後に明ら かになった一部の事項を加えて整理したものである。付 言して御了承を願う次第である。

* 诚学会詥交集： 18-67, 97 (1952)；18-67, 103 (1952)；18-72, 56 (1952)；19-80, 31 (1953) 
$G$ : Flow rate

$f:$ Cross sectional area

$p$ : Static pressure

$i$ : Enthalpy

$v=1 / \gamma:$ Specific volume

$w$ : Velocity

Subscripts :

$$
s: \text { Driving steam }
$$

$a$ : Entrained fluid

0 : Mixing chamber

1: Cross section of nozzle exit at normal expansion

$t$ : Diffuser throat inlet

$\boldsymbol{t}^{\prime}$. Diffuser throat outlet

$L$ : Distance from nozzle exit

$L_{c}$ : Distance from nozzle exit to diffuser throat inlet

$L_{t}$. Length of diffuser throat

$M$ : Molecular weight

$\left[\mathrm{kg} / \mathrm{cm}^{2}\right]$

$[\mathrm{kcal} / \mathrm{kg}]$

$\left[\mathrm{m}^{3} / \mathrm{kg}\right]$

$[\mathrm{m} / \mathrm{s}]$ [m]

[m]

[kg/kmol]

\section{Nomenclature}

$\begin{array}{cll}{[\mathrm{kg} / \mathrm{s}]} & O: \text { Surface area of steam jet } & {\left[\mathrm{m}^{2}\right]} \\ {\left[\mathrm{cm}^{2}\right]} & P: \text { Drag force of steam jet } & {[\mathrm{kg}]}\end{array}$$$
\left[\mathrm{kg} \cdot \mathrm{m} /{ }^{\circ} \mathrm{K} \cdot \mathrm{kg}\right]
$$

$R$ : Gas constant

$\boldsymbol{R}:$ Universal gas constant $\left[\mathrm{kg} \cdot \mathrm{m} /{ }^{\circ} \mathrm{K} \cdot \mathrm{kmol}\right]$
$W:$ Frictional force of diffuser wall $\quad[\mathrm{kg}]$

$w_{G t}, w_{M l}, w_{E t}:$ Mean velocities at diffuser throat inlet relative to flow rate, momentum and energy, respectively $[\mathrm{m} / \mathrm{s}]$

$T$ : Absolute temperature $\left[{ }^{\circ} \mathrm{K}\right]$

$x$ : Drag coefficient

$\chi^{\prime}$ : Drag coefficient determined experimently from entrainment performance

$\lambda$ : Coefficient of friction $\mu=G_{a} / G_{a}$ : Ratio of flow rate of entrained fluid $\xi=G_{a} / G_{a}{ }^{*}$ : Entrainment ratio

* represents the entrained fluid taken as a basis or at a base state

\section{Literature Cited}

1) Hayami, K. : Trans. Soc. Mech. Engrs. Japan, 7-28, II-11, 1941

2) Hayami, K. . Trans. Soc. Mech. Engrs. Japan, 8-31, II-25, 1942

3) Holton, W. C.: Trans. ASME, 73, 905, 1951

4) Holton, W. C., Schulz, E. J.: Trans. ASME, 73, 910, 1951

5) Sugawara, S., Hayami, K.: Trans. Soc. Mech. Engrs. Japan, 8-22, II-53, 1942

6) Takashima, Y. . Chem. Engg. Japan, 19-9, 446, 1955
7) Tanishita, I. - Riken-iho, 18-4, 239, 1939

8) Tanishita, I. : Trans. Soc. Mech. Engrs. Japan, 15-50, II-59, 1949

9) Ueda, T.: Trans. Soc. Mech. Engrs. Japan, 18-67, 97, 1952

10) Ueda, T.: Trans. Soc. Mech. Engrs. Japan, 18-67, 103, 1952

11) Ueda, T.: Trans. Soc. Mech. Engrs. Japan, 19-80, 31, 1953 


\title{
On the Characteristics of Steam Ejectors and a Method of Calculating Their Performances
}

\author{
Tatuhiro Ueda*
}

Steam ejectors can have various kinds of performance characteristics, but when high vacuum for mixing chamber or high compression ratio for entrained fluid is required for their performances, as is usual with such a case, the mixture of driving steam and entrained fluid should be kept in supersonic and fulfilled flow state at the diffuser throat inlet. The characteristics of steam ejectors in this flow state are called high vacuum characteristics.

In this flow state, the entrainment performance of an ejector, as expressed by the relation between the pressure of mixing chamber and the entrained flow rate, is determined independently of the back pressure of the diffuser. Therefore, a method of calculating the entrainment performance has been proposed, taking into consideration the drag force of steam jet from the nozzle and the entrained fluid passage area as measured cross-sectionally at the convergent part of the diffuser.

This desirable flow state depends largely on the outside conditions of the ejector. When the back pressure of the diffuser is raised above the limit value-the critical back pressure-, the high vacuum characteristics cannot be observed and the vacuum of mixing chamber will suddenly decrease. For the compression performance of the diffuser, another calculation method has been proposed for the purpose of obtaining the critical back pressure, taking into consideration the mixing of driving steam and entrained fluid with the mean velocities of the mixture relative to flow rate, momentum and energy. though, in the previous calculation methods the mixing process was neglected.

From the calculation method presented in this paper, Eq. (24) has been obtained for the entrainment ratio which is the ratio of the flow rate of entrained fluid to that of fluid taken as a basis or at a base state. Comparison of $\mathrm{Eq}$. (24) with the experimental results by Holton and Schulz ${ }^{3,4}$ has proved that the drag coefficient of steam jet $x^{\prime}$ is independent of the molecular weight of entrained fluid, but has a tendency to increase with the temperature rise of entrained fluid. If the drag coefficient $\chi^{\prime}$ and $\chi$ are kept constant, the following formula may hold which represents the fact that the flow rate of entrained fluid will be proportional to the square of dimension ratio, when ejectors are geometrically similar.

* Department of Mechanical Engineering, Tokyo University, Bunkyo-ku, Tokyo, Japan 